\title{
Avaliação no trabalho: alguns dilemas
}

DEJOURS, Chirstophe.

A avaliação do trabalho submetida à prova real.

São Paulo: Blucher, 2008. 125p.

\section{| ${ }^{1}$ Renata Perfeito Ribeiro, ${ }^{2}$ Julia Trevisan Martins |}

1 Professora assistente do Departamento de Enfermagem da Universidade Estadual de Londrina; doutoranda do Programa Interunidades da Escola de Enfermagem da Universidade de São Paulo-Ribeirão Preto. E-mail: perfeito@sercomtel.com.br

2 Doutora em Enfermagem; professora adjunta do Departamento de Enfermagem da Universidade Estadual de Londrina. E-mail: jtmartins@uel.br

A obra do francês Christophe Dejours, com organização dos brasileiros Laerte Idal Sznelwar e Fausto Leopoldo Mascia, publicada em 2008 no Brasil pela editora Blucher, está dividida em 13 capítulos. O texto é apresentado de forma didática e permite uma agradável leitura sobre o controle e a avaliação do trabalho, levando os leitores a uma reflexão crítica sobre a forma como os mesmos têm sido realizados nas instituições, chamando a atenção ainda para a maneira indiscriminada como estão sendo feitos por pessoas não capacitadas.

Diante desta constatação, o autor propõe discussões sobre o assunto, buscando melhorias para sua aplicação no trabalho, e discute questôes do poder de quem avalia, na qual o objetivo acaba não sendo o de avaliar e realizar mudanças, ou capacitaçôes com a equipe de trabalho, mas sim exercer o controle sobre as situações de trabalho, enfatizando a importância da avaliação, propondo que os avaliadores precisam ser pesquisadores com qualidades específicas para ajudar e não apenas punir as pessoas, como se vê na tradicional forma de avaliação. Ressalta que é preciso motivar o trabalhador e não desmoroná-lo.

Dejours descreve a importância da avaliação coletiva, com pensamentos no grupo de trabalho, e destaca que é necessário um grande cuidado com as avaliações individuais, prestando atenção nas promoções e também nas demissões, lembrando que as avaliações não devem ter como finalidade principal reprimir, punir, intimidar ou até mesmo castigar, mas sim ter objetivos de melhorias para a coletividade de trabalho. Como a avaliação faz parte do cotidiano de trabalho, esta atividade se faz necessária - portanto, é fundamental o aperfeiçoamento dos processos utilizados para a avaliação, 
que não sejam utilizados como forma de poder e com propostas ultrapassadas, levando em consideração as proposiçōes das instituiçōes.

$\mathrm{O}$ autor coloca que avaliar é uma atividade difícil e que não existem garantias de que esse processo proposto realmente ajude todos os sujeitos do trabalho nos processos da instituição - há que se levar em consideração cada instituição e cada ser humano com suas peculiaridades. Assim, para avaliar, é preciso conhecimento do trabalho realizado e também das características de quem o executa. A intensidade na qual o trabalho é realizado é diferente entre os trabalhadores, isto é, uma determinada atividade pode ter diferentes influências em cada ser humano. Para uns, pode ser uma carga considerada pesada, e para outras pode ser uma carga tida como leve.

E, além do estado físico do trabalhador, também se deve considerar seu fator psicológico. Para uma mesma atividade laboral, um indivíduo pode experimentar sensações de alegria ou de tristeza, prazer e sofrimento diferente de outro, na mesma atividade laboral.

As diferentes metodologias utilizadas na avaliação são apresentadas e o autor destaca o cuidado que deve ser dado à avaliação da subjetividade do trabalho e do trabalhador, quando o modo "do fazer" de cada um deve ser levado em consideração, bem como a singularidade se torna imprescindível. Para a Saúde do Trabalhador, a avaliação, da forma realizada, traz consequências para o indivíduo, propiciando o enxugamento de pessoal, com consequente aumento de trabalho para aqueles que permanecem nas instituiçōes, e corrobora para o surgimento de sentimentos de ameaça e medo da perda do trabalho, quando as avaliaçóes são feitas de forma individual e não coletivamente.

O autor conclui afirmando ser necessário flexibilizar as estruturas e as normas existentes nos processos de trabalho, e que se busquem métodos de avaliação do trabalhador menos desastrosos, com menos pressão e com mais investimento nas ciências da saúde, com enfoque para o trabalhador. ${ }^{1}$

\section{AGRADECIMENTOS}

Ao Conselho Nacional de Desenvolvimento Científico e Tecnológico (CNPq), pelo oferecimento de recursos para o aprimoramento científico através da realização do doutorado.

\section{Nota}

${ }^{1}$ Ambas as autoras participaram igualmente da elaboração desta resenha. 